\title{
Patent on umbilical-cord cells rejected in Europe...
}

[PARIS] Researchers last week won their challenge to a European patent on the use of stored stem cells from umbilical-cord blood, a technology with promising applications in bone marrow transplants and gene therapy. The patent was granted three years ago to the US company Biocyte.

Cord blood stem cells can produce red and white blood cells and platelets, and their transplantation is more effective and cheaper than the conventional practice of taking stem cells from bone marrow donors. Their lower immunogenicity, for example, reduces the risk of rejection by the patient.

But the potential threat of expensive litigation over claims of patent infringement has deterred companies and research groups from exploring new uses for cord blood cells, according to Eliane Gluckmann, a researcher at the Hôpital St Louis in Paris. "That threat has now been lifted," she says.

Gluckmann chairs Eurocord, the European Cord Blood Bank, which involves 14 research teams. It has led the challenge to the patent, along with several other organizations including the environmental group Greenpeace, the US biotechnology company Thermogenesis, and Astra Pharmaceuticals (see Nature 382, 99; 1996).
The patent covered "hematopoietic stem and progenitor cells of neonatal and fetal blood, that are cryopreserved, and the therapeutic uses of such cells upon thawing," and gave the company broad rights. The groups had opposed it on ethical grounds, arguing that it was wrong to patent human tissues. But they fought the legal battle on the basis of classical patent law, claiming that the technology described in the patent was not new.

Last week, the European Patent Office in Munich upheld their claim. According to an official, the patent "lacked novelty or an inventive step". The patent office was convinced by several papers describing similar techniques that predated the patent. The official adds that a key element was testimony by Pablo Rubenstein, a researcher at the New York Blood Center, that he had used the techniques long before the patent was applied for.

Rubenstein describes the result as a victory for proper attribution of innovation. He argues that, although the patent was defeated on legal grounds, it is also an ethical victory, as it overturns a patent on human tissues.

Neither Biocyte, which is free to appeal, nor its lawyers were available this week for comment. The patent has already been rejected in the United States and Japan. Declan Butler

\section{as US bid to patent human-animal hybrid fails}

[LONDON] The US Patent and Trademark Office has rejected a provocative patent application filed by two prominent biotechnology critics on techniques for combining human and animal cells to create hybrids or chimaera.

The patent was filed by researcher Stuart Newman of New York Medical College, a prominent member of the Council for Responsible Genetics, and Jeremy Rifkin, president of the lobbying group the Foundation on Economic Trends. Both are keen to open up political debate on what can and cannot be patented when human cells are involved (see Nature 392, 423; 1998).

In rejecting the

application, the patent office lists prominently among its objections the fact that "the claimed invention as a whole embraces a human being", and that its subject matter therefore lies outside the scope of US patent law.

The examiner who rejected the application admitted that the patenting of human beings was not explicitly ruled out in an earlier judgement, the famous Chakrabarty case in the early 1980s which cleared the way for patents on living organisms - and the growth of the US biotechnology industry.

The examiner lists a variety of reasons for rejecting the application, including the fact that several previous efforts at introducing human cells into animal tissues have been described in the scientific literature. She also argues that, despite the Chakrabarty judgement, in drawing up patent legislation "Congress did not intend [the US Patent Act] to include the patenting of human beings".

\section{But Pat Coyne, the}

Washington-based attorney who is handling the patent application, says: "We do not think this is a proper ground to reject the application. We feel that the key issue is: what does it mean to 'embrace' a human being? How does the patent office get the authority to say that, because in its extreme form our claimed invention could do this, it is not patentable?"

Rifkin says: "No parliament in the world is going to be keen to debate how much human genetic information [in a chimaeric organism] makes up a human being. But we want to force them to do it." He and Newman are appealing against the rejection of their application.

David Dickson
[WASHINGTON] The US Civilian Research and Development Foundation (CRDF), set up to aid scientists in the former Soviet Union, may return to its original practice of sponsoring basic, investigator-initiated research if a hefty increase in funds proposed by the Clinton administration is approved by Congress.

The CRDF, which awards grants averaging $\$ \mathbf{5 0 , 0 0 0}$ for joint research between scientists in the United States and the former Soviet Union, was set up in 1995 under the auspices of the National Science Foundation, using $\$ 5$ million in start-up funds from the US Defense Department and \$10 million from philanthropist George Soros (see Nature 375, 170; 1995). The foundation's budget is around $\$ 10$ million a year.

Principal support has come from the National Science Foundation, the National Institutes of Health and the Department of State. Another 35 or so US agencies have used the CRDF as a conduit for funding cooperative projects with former Soviet Union scientists, according to Gloria Duffy, chief executive of the Commonwealth Club of California, and chair of the foundation's board of directors.

While that has kept the money flowing, it has confined the research agenda to areas of interest to sponsors. According to Duffy, the CRDF wants a separate endowment to enable it to return to its original practice of funding a range of investigator-proposed research, rather than merely "performing a federal agency's task".

At a conference held in Washington last week to highlight results from CRDF collaborations, White House science adviser Neal Lane reiterated the administration's support for increased aid to Russian scientists. President Bill Clinton has proposed that spending should be tripled from $\$ 64$ million this year to $\$ \mathbf{1 7 6 . 5}$ million in $\mathbf{2 0 0 0}$. Annual funding for the CRDF would increase from $\$ 10$ million to $\$ 23.5$ million, and it would receive $\$ 111$ million over five years.

Support for the CRDF is strong in Congress, claims Duffy. But factors such as US-Russian tensions over the war in Kosovo and concerns about security in US government laboratories make it difficult to predict whether law-makers will grant the administration's spending request.

The proposed boost comes at a critical time for former Soviet Union scientists. With the Russian government unable to support its own research establishment, and with Soros pulling back on his commitments (see page 628), Russian scientists have become heavily dependent on US and European aid to continue their work.

Tony Reichhardt 